\title{
Vertical habitat utilization by tagged yellowfin tuna (Thunnus albacares) released in the Revillagigedo Archipelago Biosphere Reserve, Mexico
}

\section{Utilización del hábitat vertical del atún aleta amarilla (Thunnus albacares) marcado y liberado en la Reserva de la Biosfera Archipiélago de Revillagigedo, México}

\author{
Gabriel Aldana-Flores ${ }^{1,2}$, Michel Dreyfus-León ${ }^{3 *}$, Kurt M Schaefer ${ }^{4}$, Juan Madrid-Vera ${ }^{1}$, \\ Daniel W Fuller ${ }^{4}$, Sergio G Castillo-Vargamachuca ${ }^{2}$ \\ ${ }^{1}$ Instituto Nacional de Pesca y Acuacultura-Mazatlán, Calzada Sábalo Cerritos s/n, contiguo Estero El Yugo, \\ CP 82010, Mazatlán, Sinaloa, Mexico. \\ 2 Posgrado en Ciencias Biológico Agropecuarias, Universidad Autónoma de Nayarit, Carretera Tepic- \\ Compostela, km 9, CP 63780, Nayarit, Mexico. \\ ${ }^{3}$ Instituto Nacional de Pesca y Acuacultura-Ensenada, km 97.5 Carretera Tijuana-Ensenada, s/n, Col. El Sauzal \\ de Rodríguez, CP 22760, Ensenada, Baja California, Mexico. \\ ${ }^{4}$ Inter-American Tropical Tuna Commission, 8604 La Jolla Shores Drive, La Jolla, CA, 92037-1508, USA. \\ * Corresponding author. E-mail: dreyfus@cicese.mx
}

\begin{abstract}
A description of vertical habitat use by yellowfin tuna, Thunnus albacares, captured and released with archival tags in the Revillagigedo Archipelago Biosphere Reserve, Mexico, during the 2006-2011 period is given. An analysis was made of internal and ambient temperatures, depth, and time of day registered in 68 archival tags recovered from tuna caught mostly in sets associated with dolphins by Mexican purse-seine vessels. Tuna were classified into 3 age groups (I, II, and III) for analyses. Vertical movements were analyzed by dividing the water column into 10 depth strata. The 3 age groups remained the longest in the uppermost stratum ( $0-25 \mathrm{~m})$, and their presence began to diminish in subsequent strata, with some occasional visits at $>500-\mathrm{m}$ depths. In the $>500 \mathrm{~m}$ stratum, age group III was the one with the longest time investment with $45 \mathrm{~min}$ on average. Presence at different depths throughout the day showed significant differences among age groups (Wald's test expressed as $\chi^{2}, P<0.05$ ). The physiological adaptation of yellowfin tuna to maintain minimal changes in its internal temperature at different depths gives it the advantage to expand its food search to deep zones where temperature oscillates around $5^{\circ} \mathrm{C}$.
\end{abstract}

Key words: yellowfin tuna, archival tag, age group, depth, vertical migrations.

RESUMEN. Se describe el uso del hábitat vertical del atún aleta amarilla, Thunnus albacares, capturado y liberado con marca archivadora en la Reserva de la Biosfera Archipiélago de Revillagigedo, México, durante el periodo 2006-2011. Se analizó la serie de datos de temperatura interna, temperatura del ambiente, profundidad y hora del día almacenados en 68 marcas archivadoras recuperadas de los atunes capturados, en su mayoría, en lances pesqueros asociados a delfines por barcos cerqueros atuneros de bandera Mexicana. Los atunes fueron clasificados para su análisis en 3 grupos de edad (I, II y III). Los movimientos verticales se analizaron dividiendo la columna de agua en 10 estratos de profundidad. Los 3 grupos de edad invirtieron más tiempo en el estrato superficial (0-25 $\mathrm{m})$ y su presencia fue disminuyendo a medida que fue aumentando la profundidad, con visitas ocasionales a profundidades mayores que $500 \mathrm{~m}$. En el estrato de $>500 \mathrm{~m}$, el grupo de edad III, fue el que más tiempo invirtió con un promedio de $45 \mathrm{~min}$. La presencia a diferentes profundidades a lo largo del día mostró diferencias significativas entre los grupos de edad (prueba $\chi^{2}$ de Wald, $P<0.05$ ). La adaptación fisiológica del AAA para mantener cambios mínimos en su temperatura interna a diferentes profundidades es una ventaja para ampliar la búsqueda de alimento en zonas profundas donde la temperatura del ambiente osciló alrededor de los $5^{\circ} \mathrm{C}$.

Palabras clave: atún aleta amarilla, marca archivadora, grupo de edad, profundidad, migraciones verticales

\section{INTRODUCTION}

The main catches of yellowfin tuna (YFT) (Thunnus albacares) in the eastern Pacific Ocean (EPO) are obtained by fisheries that use purse-seine fishing gear. In the YFT fishery, the Mexican tuna fleet lands the largest annual catch volumes (IATTC 2018). The Mexican fleet mainly detects and captures YFT in the EPO when the tuna are associated with dolphins, are found as free schools of fish,

\section{INTRODUCCIÓN}

Las principales capturas de atún aleta amarilla (AAA) (Thunnus albacares) en el océano Pacífico oriental (OPO) son obtenidas por la pesquería que utiliza como arte de pesca la red de cerco. De esta pesquería, la flota atunera mexicana es la que aporta, anualmente, los mayores volúmenes de captura (IATTC 2018). La flota mexicana detecta y captura AAA en el OPO, principalmente, cuando se encuentra asociado a 
and are associated with floating objects, although catch volumes are low in the case of the latter (Aldana 2000, Dreyfus 2008, IATTC 2016). YFT movements in the EPO have been of interest to the Inter-American Tropical Tuna Commission (IATTC); their research began in 1950 with a fish tagging program that involved the use of conventional tags to study the movements of YFT of different sizes (Schaefer et al. 1963). Recently, tagging studies have been conducted using archival tags to analyze the horizontal and vertical movements of YFT and other tuna species. Bigeye tuna (Thunnus obesus) reportedly prefer swimming at shallow depths $(0-25 \mathrm{~m})$ at night and deeper depths $(200-350 \mathrm{~m})$ during the day (Schaefer and Fuller 2010). By contrast, the vertical movement of YFT is characterized by extended periods spent at a depth of $100 \mathrm{~m}$ both during the day and at night, and brief visits to depths of $150-250 \mathrm{~m}$ and occasionally $500 \mathrm{~m}$ (Schaefer et al. 2007, 2011, 2014).

The YFT is an epipelagic species that inhabits tropical and subtropical waters (Collette and Nauen 1983), with physiological adaptations to maintain its internal temperature above water temperature (Graham 1975). Internal temperature regulation rates in different fish size groups and the ability to remain at deeper depths with minimal oxygen concentrations determine the frequency and dwell time of YFT in deep zones (Brill et al. 1998, Schaefer et al. 2011). This behavior was observed in tuna from age groups I and II, which spent a higher percentage of time $(64.5-84.5 \%)$ at depths of less than $100 \mathrm{~m}$ than fish from age groups III, IV, and $\mathrm{V}$, which spent a lower percentage of time in the first $100 \mathrm{~m}(43-56 \%)$ and showed higher tolerance to lower temperatures and oxygen concentrations (Schaefer et al. 2011, Schaefer et al. 2014).

The EPO is characterized by a shallow oxygen minimum zone and by an anoxic water layer below the thermocline. The depth of the thermocline decreases towards the coast, but the maximum depth in the area from $120^{\circ} \mathrm{W}$ to the coast does not exceed an average depth of $100 \mathrm{~m}$ (Fiedler and Lynne 2006, Hinton 2015, Portela et al. 2016). The physiological adaptations of YFT allow them to regularly descend to deeper waters in order to feed, but they remain there for short periods because of the synergistic effects of low ambient temperatures and minimal oxygen concentrations (Schaefer et al. 2014, Hinton 2015). The objective of this study was to determine the depth preferences, during day and night hours, of YFT from different age groups and tagged with archival tags in the Revillagigedo Archipelago Biosphere Reserve, a protected natural area.

\section{Materials AND METHOdS}

This study used data from the project "Tagging of Yellowfin Tuna (Thunnus albacares) in the protected natural area of the Revillagigedo Archipelago Biosphere Reserve, Mexico," carried out jointly by IATTC and the National delfines, como cardumen libre y, aunque con bajas capturas, asociado a objetos flotantes (Aldana 2000, Dreyfus 2008, IATTC 2016). Los desplazamientos del AAA en el OPO han sido del interés de la Comisión Interamericana del Atún Tropical (CIAT), cuya investigación inició en 1950 con un programa de marcado que utilizaba marcas convencionales para estudiar los movimientos del AAA de diferentes longitudes de tallas (Schaefer et al. 1963). Recientemente, se han llevado a cabo estudios de marcado mediante el uso de marcas archivadoras para analizar los desplazamientos horizontales y verticales del AAA y de otras especies de túnidos. En el caso del atún patudo (Thunnus obesus), fue detectado un patrón de comportamiento en su nado vertical, ya que prefirió profundidades someras $(0-25 \mathrm{~m})$ durante las horas de la noche y zonas más profundas $(200-350 \mathrm{~m})$ durante las horas del día (Schaefer y Fuller 2010). En contraste, el movimiento vertical del AAA se caracterizó por el mayor tiempo de permanencia en el día y la noche en la capa dentro de los $100 \mathrm{~m}$ de profundidad y por las visitas breves a zonas profundas de 150-250 m y, ocasionalmente, más allá de los $500 \mathrm{~m}$ (Schaefer et al. 2007, 2011, 2014).

El AAA es una especie epipelágica que habita aguas tropicales y subtropicales (Collette y Nauen 1983) y posee una adaptación fisiológica para mantener su temperatura interna por arriba de la temperatura del agua (Graham 1975). La velocidad a la que regulan la temperatura interna los diferentes grupos de talla y la capacidad de permanecer a profundidades con concentraciones mínimas de oxígeno determinan la frecuencia y el tiempo de permanencia del AAA en zonas profundas (Brill et al. 1998, Schaefer et al. 2011). Este comportamiento fue observado en atunes de grupos de edad I y II, que exhibieron un mayor porcentaje (rango del $64.5 \%$ al $84.5 \%$ ) de permanencia a profundidades menores que $100 \mathrm{~m}$, en comparación con los grupos de edad III, IV y V, que disminuyeron su porcentaje de estadía en los primeros $100 \mathrm{~m}$ (rango del $43 \%$ al 56\%) y exhibieron mayor tolerancia a las bajas temperaturas y concentraciones de oxígeno (Schaefer et al. 2011, Schaefer et al. 2014).

El OPO se caracteriza por presentar una zona de oxígeno mínimo poco profunda y una capa anóxica debajo de la termoclina. La profundidad de la termoclina disminuye hacia la costa, pero la profundidad máxima en la zona comprendida entre los $120^{\circ} \mathrm{W}$ y la costa no rebasa, en promedio, los $100 \mathrm{~m}$ de profundidad (Fiedler y Lynne 2006, Hinton 2015, Portela et al. 2016). La adaptación fisiológica del AAA le permite descender regularmente a aguas más profundas para alimentarse, pero permanece ahí poco tiempo debido a los efectos sinérgicos de las bajas temperaturas del ambiente y las mínimas concentraciones de oxígeno (Schaefer et al. 2014, Hinton 2015). El presente estudio tiene como objetivo conocer la preferencia de profundidades durante las horas del día y de la noche de los diferentes grupos de edad de los AAA marcados con marcas archivadoras en el área natural protegida de la Biosfera Archipiélago de Revillagigedo. 
Fisheries and Aquaculture Institute (Mexico) during the 2006-2011 period. YFT were captured, tagged, and released in waters near the 4 islands that compose the Revillagigedo Archipelago Biosphere Reserve (DOF 1994): San Benedicto, Socorro, Roca Partida, and Clarión. The sport fishing vessel M/B Royal Star (US flag) was used for fish catching and tagging. Each fishing trip involved an average of 18 crew members (captain, crew, and scientists), who carried out catching and tagging activities. The fishing trips were conducted annually in February, with a duration of 9 effective days of fishing. The 2 models of archival tags used, LTD_2310 and Mk9, were manufactured by Lotek Wireless (Ontario, Canada) and Wildlife Computers (Redmond, Washington, USA), respectively. The characteristics of archival tags and the tagging procedure for YFT were previously described by Schaefer et al. (2007) and Schaefer and Fuller (2016). Fork length (in centimeters) of each tagged was recorded. Fish age was calculated in years and days using the obtained fork length and the growth equation outlined by Wild (1986). The total number of days of freedom was calculated as the number of days that were added to the number of years of the age group in which the YFT was classified at the time of its release.

To determine the vertical circadian habitat preferences of YFT by age group and time of day, depths were divided into the following strata: $0-25 \mathrm{~m}, 26-50 \mathrm{~m}$, 51-75 m, 76-100 m, 101-125 m, 126-150 m, 151-175 m, 176-200 m, 200-500 m, and $>500 \mathrm{~m}$. The number of records collected per hour in each stratum was counted by age group. The hours were grouped into hours of the day (6:00 to 18:00) and night (19:00 to 5:00), depending on the activity of the Mexican fleet (DOF 1999, DOF 2014). A "deep zone" was defined as a zone that was deeper than $50 \mathrm{~m}$, which is the average depth of the mixed layer (Portela et al. 2016). The ambient temperatures were used to describe the prevailing environmental conditions at different depths.

Dwell time of YFT by hour and age group at the different depth strata was analyzed by means of the type III Wald $\chi^{2}$ test (Montgomery 1991, Lyman 1993, Quinn and Keough 2002).

\section{ReSUlts}

A total of 68 archival tags were analyzed out of 88 tags recovered between 2006 and 2012. Seven tags recovered by a recreational fleet were discarded, as well as all tags recovered in less than $30 \mathrm{~d}$ after the fish were released and tags with corrupted data. Of the 68 tags, 38 were recovered from YFT tagged on Clarion Island, 10 from YFT tagged on Roca Partida Island, 16 from YFT tagged on Socorro Island, and 4 from YFT tagged on San Benedicto Island. The number of days after the release varied from 32 to 1,139 , with those extremes corresponding to one individual tagged on Clarion Island and another on San Benedict Island, respectively. The age groups with the highest representation were, in order

\section{Materiales y Métodos}

Se utilizó la información generada por el proyecto "Marcado de Atún Aleta Amarilla (Thunnus albacares) en el área natural protegida de la Reserva de la Biosfera del Archipiélago de Revillagigedo, México", llevado a cabo conjuntamente por la CIAT y el Instituto Nacional de Pesca y Acuacultura (México) durante el periodo 2006-2011. Las actividades de captura, marcado y liberación del AAA se realizaron en las aguas colindantes con las 4 islas que conforman la Reserva de la Biosfera Archipiélago de Revillagigedo (DOF 1994): San Benedicto, Socorro, Roca Partida y Clarión. Para la captura y el marcado, se utilizó la embarcación de pesca deportiva B/M Royal Star (de bandera estadounidense). En cada viaje de pesca participaron un promedio de 18 tripulantes (capitán, tripulación y científicos), que llevaron a cabo las actividades de captura y marcado. Los viajes de pesca se realizaron anualmente en febrero, con una duración de 9 días efectivos de pesca. Los tipos de marcas archivadoras utilizadas correspondieron a los modelos LTD_2310 y Mk9, fabricados por Lotek Wireless (Ontario, Canadá) y Wildlife Computers (Redmond, Washington, EUA), respectivamente. Las características de las marcas archivadoras y el procedimiento para su implantación en el AAA están descritas en Schaefer et al. (2007) y Schaefer y Fuller (2016). Se registró la longitud furcal, en centímetros, de cada AAA marcado. Con la longitud furcal obtenida y la ecuación de crecimiento de Wild (1986), se calculó la edad del pez en años y días. El total de días en libertad analizados fue le número de días que complementaron al grupo de edad al que el AAA fue clasificado al momento de su liberación.

Para conocer la preferencia de hábitat vertical circa diaria del AAA por grupo de edad y hora del día, las profundidades fueron divididas en los siguientes estratos: 0-25 m, 26-50 m, 51-75 m, 76-100 m, 101-125 m, 126-150 m, 151-175 m, $176-200 \mathrm{~m}, 200-500 \mathrm{~m}$ y $>500 \mathrm{~m}$. Para cada estrato de profundidad, se contabilizó, por grupo de edad, el total de registro por hora. Las horas fueron agrupadas en horas del día (06:00 a 18:00) y horas de la noche (19:00 a 05:00), en función de la actividad de la flota mexicana (DOF 1999, 2014). Se definió como "zona profunda" aquella zona cuya profundidad se extendió más allá de los $50 \mathrm{~m}$, que es el grosor promedio de la capa de mezcla (Portela et al. 2016). La temperatura del ambiente fue utilizada para describir las condiciones ambientales prevalecientes a diferentes profundidades.

La permanencia del AAA por hora en los diferentes estratos de profundidad, por grupo de edad, fue analizada mediante la prueba $\chi^{2}$ de Wald, suma tipo 111 (Montgomery 1991, Lyman 1993, Quinn y Keough 2002).

\section{Resultados}

Se analizaron 68 marcas archivadoras de un total de 88 marcas recuperadas durante el periodo 2006-2012. Se descartaron 7 marcas recuperadas por la flota deportiva recreativa 
of importance, II, I, and III, with 44, 13, and 11 specimens, respectively. The fish were recaptured by the purse-seine fleet, being 41 from dolphin sets and 27 from school sets (Fig. 1, Table 1).

\section{Age group vs depth}

The number of records in different depth strata was counted by age group (I, II, and III). The sum of records for the 3 age groups was concentrated in the first 2 strata $(0-25 \mathrm{~m}$ and $26-50 \mathrm{~m})$, whereas the remaining records were distributed in the other strata in descending order, with the smallest number being found in the deepest stratum $(>500 \mathrm{~m})$. Age groups I, II, and III had the longest dwell time in the $0-25 \mathrm{~m}$ stratum, with $72 \%, 65 \%$, and $63 \%$ of the time (corresponding to 17,15 , and $15 \mathrm{~h}$ ), respectively. The stratum with the second longest dwell time was $26-50 \mathrm{~m}$, with $16 \%, 17 \%$, and $17 \%$ of the time for age groups I, II, and III, respectively. The 51-75 $\mathrm{m}$ and $76-100 \mathrm{~m}$ depth strata were frequently visited by the 3 age groups, but dwell time there decreased to less than $12 \%$. Overall, YFT from age groups I, II, and III spent $98 \%, 94 \%$, and $91 \%$ of the daytime, respectively, at a depth of $0-100 \mathrm{~m}$. Age groups II and III visited the remaining depth strata $(101-500 \mathrm{~m})$ more often than age group I, although the percentage of time spent at these depths was minimal. y todas aquellas marcas recuperadas con menos de $30 \mathrm{~d}$ de haberse liberado el atún o con algún problema de almacenamiento de datos. De las 68 marcas, 38 correspondieron a AAA marcados en isla Clarión, 10 a AAA marcados en isla Roca Partida, 16 a AAA marcados en isla Socorro y 4 a AAA marcados en isla San Benedicto. El rango de días en libertad fue de un mínimo de 32 a un máximo de 1,139, que correspondieron a un individuo marcado en isla Clarión y otro en isla San Benedicto, respectivamente. Los grupos de edad con mayor representación fueron, en orden de importancia, el II, el I y el III, con 44, 13 y 11 AAA, respectivamente. Estos atunes fueron recapturados por la flota atunera con red de cerco: 41 atunes en lances sobre cardúmenes asociados a delfines y 27 en lances sobre cardúmenes no asociados (Fig. 1, Tabla 1).

\section{Grupo de edad vs profundidad}

El número de registros a diferentes profundidades fue contabilizado para los diferentes estratos de profundidad por grupo de edad (I, II y III). La suma de registros para los 3 grupos de edad se concentró en los primeros 2 estratos de profundidad (0-25 $\mathrm{m}$ y $26-50 \mathrm{~m})$, mientras que el resto de los registros se distribuyó en los demás estratos de manera descendente en función de la profundidad, con el menor número de registros en el estrato de $>500 \mathrm{~m}$. Los grupos de edad I, II y III presentaron la mayor permanencia en el estrato de $0-25 \mathrm{~m}$,

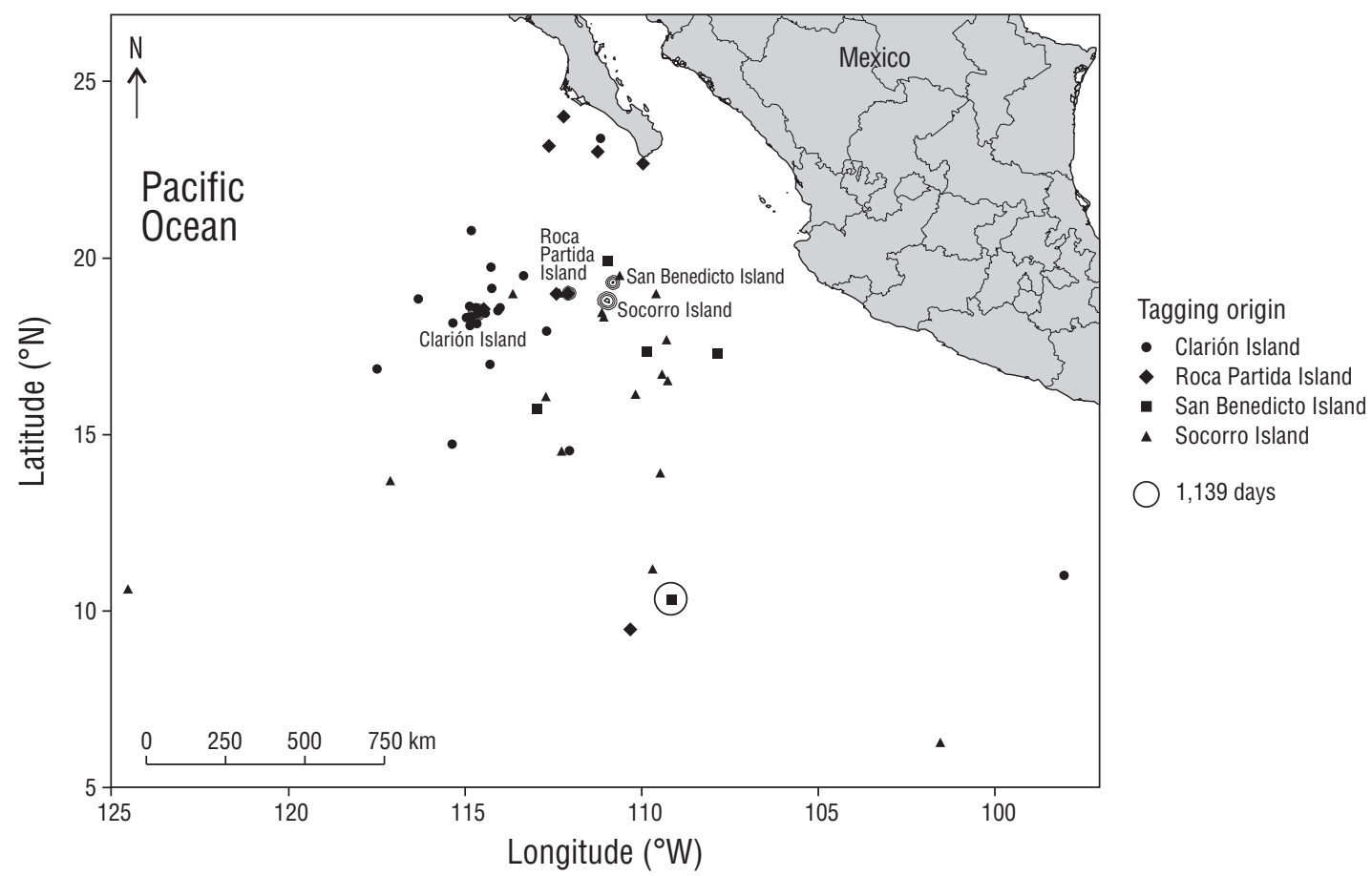

Figure 1. Recapture locations (symbols) for 68 yellowfin tuna, Thunnus albacares, that were tagged during the 2006-2012 period off the islands that make up the Revillagigedo Archipeago Biosphere Reserve.

Figura 1. Localización de la recaptura (símbolos) de los 68 ejemplares de atún aleta amarilla, Thunnus albacares, marcados en las diferentes islas que conforman la Reserva de la Biosfera Archipiélago de Revillagigedo durante el periodo 2006-2012. 


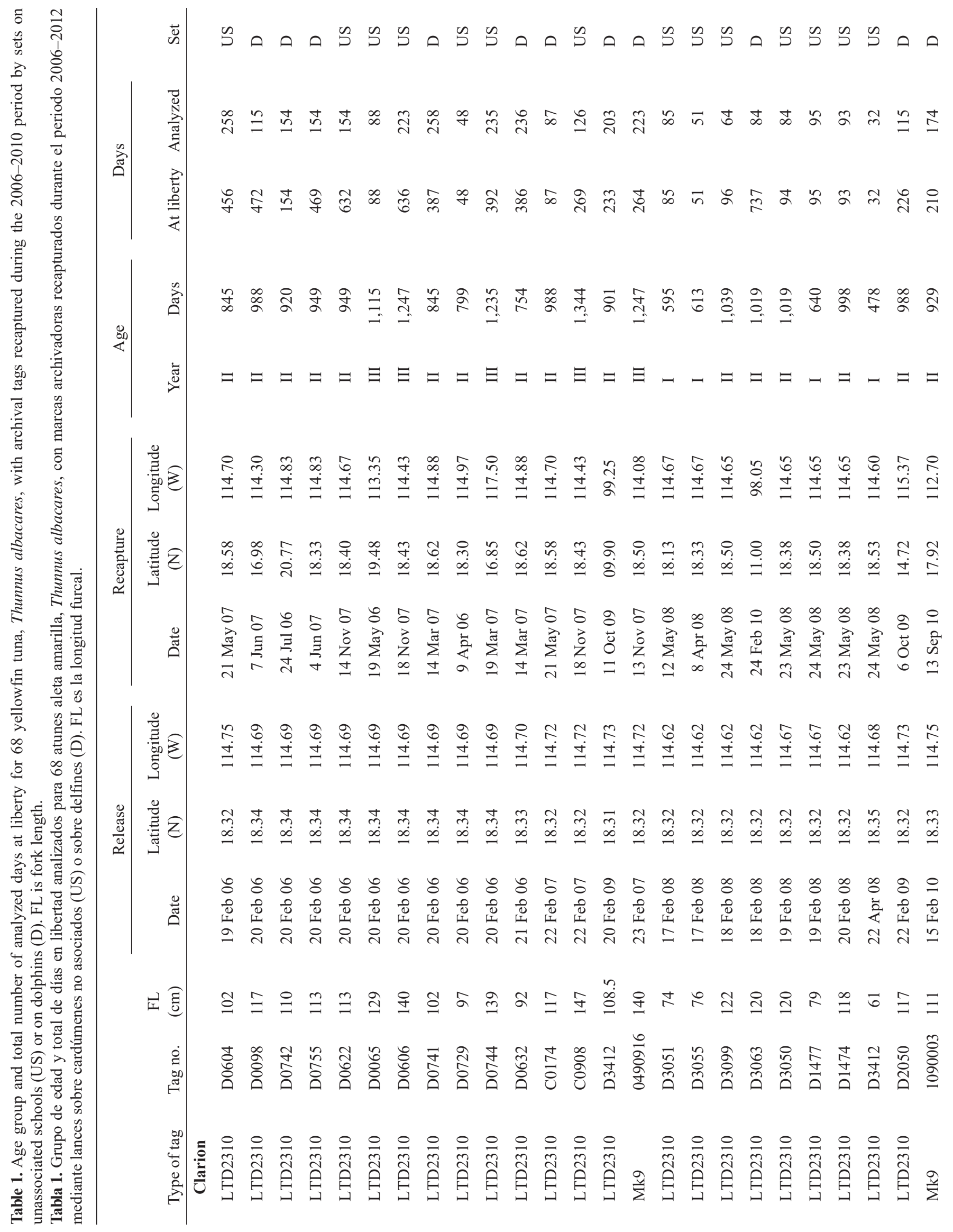




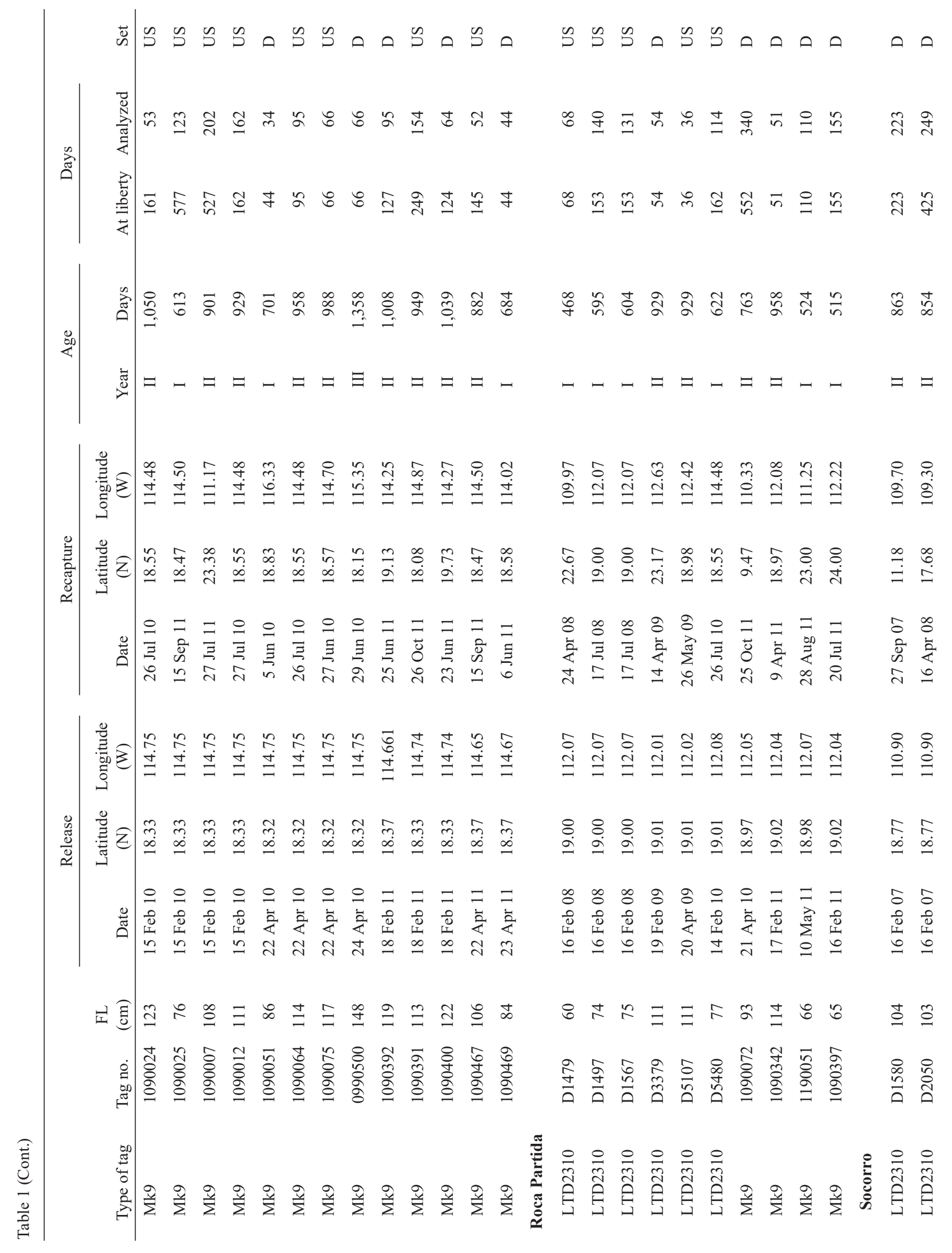


Aldana-Flores et al.: Vertical habitat use by yellowfin tuna

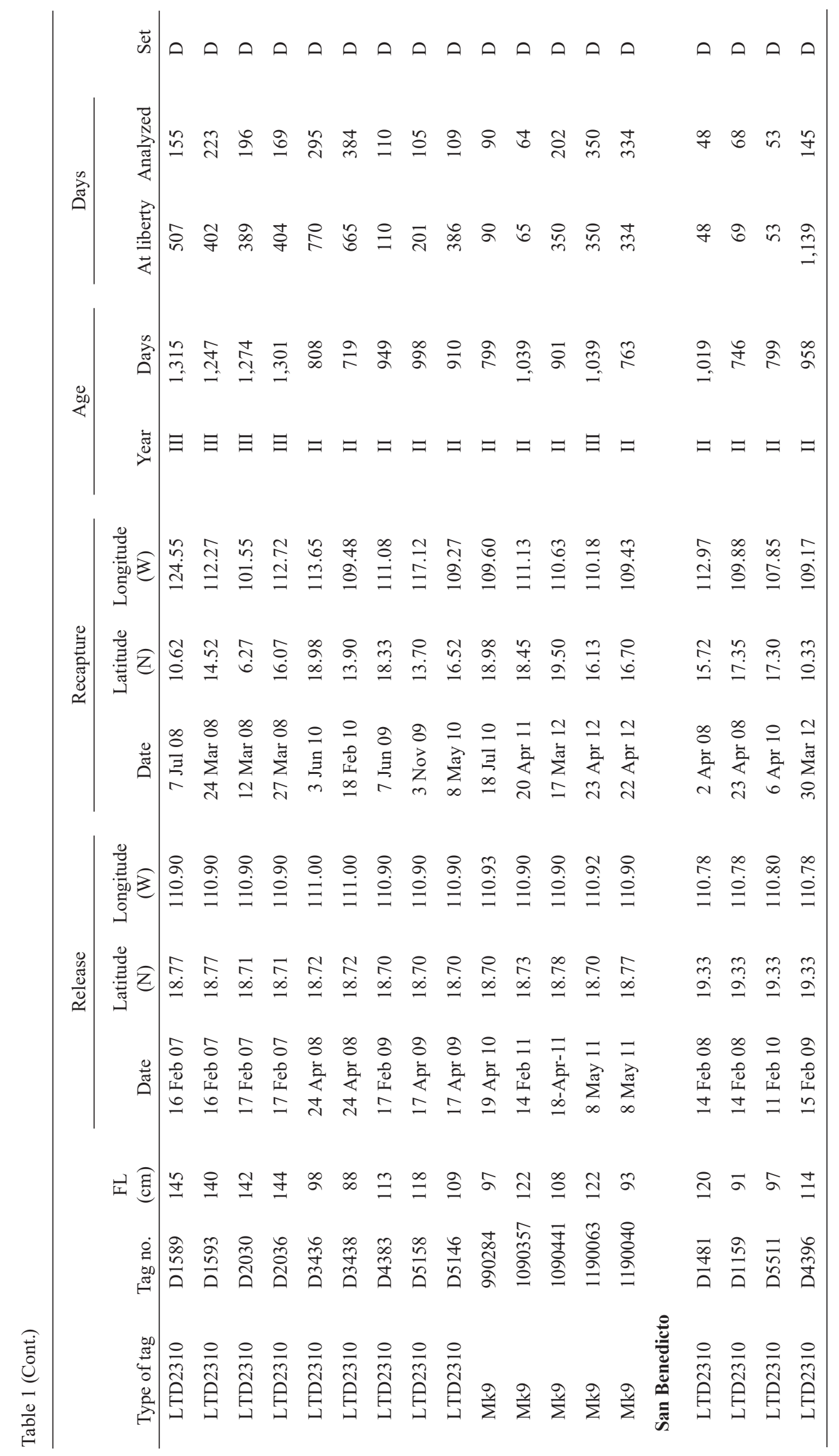




\section{Deep zone (>500 m)}

The total number of tuna that dove beyond $500 \mathrm{~m}$ depth by age group was 1 for group I, 5 for group II, and 5 for group III. Maximum recorded depth was $746 \mathrm{~m}$ for group I, 1,240 m for group II, and 1,432 $\mathrm{m}$ for group III. The number of visits to deep zones made by each age group was 3 for group I, 10 for group II, and 5 for age group III. Average dwell time was $10 \mathrm{~min}$ for group I, $24 \mathrm{~min}$ for group II, and $47 \mathrm{~min}$ for group III (Table 2).

\section{Behavior and habitat use by time of day}

There were significant differences in the number of fish in different depth strata during day and night hours $\left(\chi^{2}[18]=38.963, P<0.00288\right)$ between age groups I, II, and III.

\section{Age group I}

Age group I remained longer in the $0-25 \mathrm{~m}$ depth stratum, corresponding to 30 to $53 \mathrm{~min} \cdot \mathrm{h}^{-1}$ (average of $42 \mathrm{~min})$. The time spent in this stratum was longer $(50 \mathrm{~min})$ from 03:00 to 11:00, but subsequently decreased from 12:00 to 24:00, with no more than $35 \mathrm{~min} \cdot \mathrm{h}^{-1}$. The stratum with the second longest dwell time was $26-50 \mathrm{~m}$, corresponding to $6-15 \mathrm{~min} \cdot \mathrm{h}^{-1}$ (average of $10 \mathrm{~min}$ ). The longest times in this stratum were recorded from 12:00 to 03:00, with a limit of up to $15 \mathrm{~min} \cdot \mathrm{h}^{-1}$. In these 2 strata $(0-25$ and $26-50 \mathrm{~m}$ ), the total dwell time was $53 \mathrm{~min}$. In the remaining strata $(51-500 \mathrm{~m})$, dwell time decreased with depth, with visits to the deep zones being more frequent from 13:00 to 01:00. With respect to the deepest stratum $(>500 \mathrm{~m})$, age group I made 3 visits, 2 during the night (02:00 and 05:00) and 1 during the day (09:00). The time spent at these depths was 7-12 min, with an average of $10 \mathrm{~min}$. The deepest swim (746 m) was made at 09:00 and lasted 12 min (Fig. 2).

Table 2. Depth and time spent at depth by age group for yellowfin tuna, Thunnus albacares, that dove $>500 \mathrm{~m}$.

Tabla 2. Profundidad y tiempo de permanencia por grupo de edad para los atunes aleta amarilla, Thunnus albacares, que realizaron inmersiones a profundidades $>500 \mathrm{~m}$.

\begin{tabular}{ccccccccc}
\hline \multirow{2}{*}{$\begin{array}{c}\text { Age } \\
\text { group }\end{array}$} & $\begin{array}{c}\text { No. of } \\
\text { fish }\end{array}$ & $\begin{array}{c}\text { Deep } \\
\text { dives }\end{array}$ & \multicolumn{2}{c}{ Range } & Average & & Range & Average \\
I & 1 & 3 & $500-746$ & 685 & & $7-12$ & 10 \\
II & 5 & 10 & $500-1,240$ & 1,003 & & $8-65$ & 24 \\
III & 5 & 7 & $500-1,432$ & 1,236 & & $20-70$ & 47 \\
\hline
\end{tabular}

con el $72 \%, 65 \%$ y $63 \%$ del tiempo, lo que corresponde a unas 17,15 y $15 \mathrm{~h}$, respectivamente. El siguiente estrato donde hubo permanencia importante fue el de $26-50 \mathrm{~m}$, con el $16 \%$, $17 \%$ y $17 \%$ del tiempo para los grupos de edad I, II y III, respectivamente. Los estratos de profundidad de 51-75 $\mathrm{m}$ y 76-100 m fueron visitados con frecuencia por los 3 grupos de edad, pero la permanencia ahí disminuyó a porcentajes inferiores al $12 \%$. En general, los AAA de los grupos de edad I, II y III invirtieron, respectivamente, el $98 \%, 94 \%$ y $91 \%$ de su tiempo del día en permanecer dentro de $0-100 \mathrm{~m}$ de profundidad. Los grupos de edad II y III visitaron los restantes estratos de profundidad (de $101 \mathrm{~m}$ hasta $500 \mathrm{~m}$ ) en mayor grado que el grupo de edad I, aunque el porcentaje de tiempo a esas profundidades fue mínimo.

\section{Zona profunda $(>500 \mathrm{~m})$}

El número total de atunes que realizaron inmersiones más allá de los $500 \mathrm{~m}$ de profundidad, por grupo de edad, fue 1 para el grupo I, 5 para el grupo II y 5 para el grupo III. La profundidad máxima registrada fue $746 \mathrm{~m}$ para el grupo I, 1,240 m para el grupo II y 1,432 m para el grupo III. El número de inmersiones realizadas por grupo de edad fue 3 para el grupo I, 10 para el grupo II y 5 para el grupo III. El tiempo promedio de permanencia fue $10 \mathrm{~min}$ para el grupo I, 24 min para el grupo II y $47 \mathrm{~min}$ para el grupo III (Tabla 2).

\section{Comportamiento y utilización del hábitat por hora del día}

La presencia de atunes en los distintos estratos de profundidad durante las horas del día y de la noche arrojó diferencias significativas $\left(\chi^{2}[18]=38.963, P<0.00288\right)$ entre los grupos de edad I, II y III.

\section{Grupo de edad I}

El grupo de edad I permaneció por más tiempo en el estrato de profundidad de 0-25 m, con un rango de tiempo de 30 a $53 \mathrm{~min} \cdot \mathrm{h}^{-1}$ (promedio de $42 \mathrm{~min}$ ). El tiempo de permanencia en este estrato fue mayor (50 min) de las 03:00 a las 11:00, pero posteriormente disminuyó de las 12:00 a las 24:00, con un tiempo de permanencia no mayor que $35 \mathrm{~min} \cdot \mathrm{h}^{-1}$. El segundo estrato de profundidad donde los AAA permanecieron un tiempo considerable fue el de 26-50 m, con un rango de tiempo de 6 a $15 \mathrm{~min} \cdot \mathrm{h}^{-1}$ (promedio de $10 \mathrm{~min}$ ). Los mayores tiempos de permanencia en este estrato fueron registrados desde las 12:00 hasta las 03:00, con un límite de hasta $15 \mathrm{~min} \cdot \mathrm{h}^{-1}$. Entre los 2 estratos de profundidad $(0-25 \mathrm{~m} \mathrm{y}$ 26-50 m), la permanencia sumó a $53 \mathrm{~min}$. Para el resto de los estratos (de 51 a $500 \mathrm{~m}$ ), la permanencia fue disminuyendo a mayor profundidad, y fueron más consistentes las inmersiones a zonas profundas en un horario de 13:00 a 01:00. Con respecto al estrato de mayor profundidad $(>500 \mathrm{~m})$, el grupo de edad I realizó 3 visitas, 2 en la noche (02:00 y 05:00) y 


\section{Age group II}

Dwell time was longer in the $0-25 \mathrm{~m}$ depth stratum, corresponding to 35 to $53 \mathrm{~min}$ (average of $38 \mathrm{~min}$ ) spent per hour. The longest times spent in that stratum were recorded from 01:00 to 11:00 and varied from 40 to $53 \mathrm{~min}$. Nonetheless, dwell time decreased from 12:00 to 24:00 a.m., corresponding to $23-34 \mathrm{~min}$. The other depth stratum where age group II remained for a considerable time was at $26-50 \mathrm{~m}$, corresponding to 6-15 $\mathrm{min}$ (average of $10 \mathrm{~min}$ ). The longest dwell times in this stratum were recorded from 12:00 to $24: 00 \mathrm{a} . \mathrm{m}$. and varied from 12 to $15 \mathrm{~min} \cdot \mathrm{h}^{-1}$. In these 2 strata $(0-25$ and $26-50 \mathrm{~m})$, the average dwell time was $48 \mathrm{~min} \cdot \mathrm{h}^{-1}$. In the remaining strata $(51-500 \mathrm{~m})$, dwell time decreased with depth, with dives to deep zones being more frequent from 13:00 to 24:00. Regarding the deepest stratum $(>500 \mathrm{~m})$, age group II made 10 visits, 6 during the day (08:00 to 16:00) and 4 during the night (20:00 to 04:00). The time spent at these depths was 8 to $65 \mathrm{~min}$, with an average of $24 \mathrm{~min}$. The deepest swim $(1,240 \mathrm{~m})$ was made at 02:00 and lasted $32 \mathrm{~min}$ (Fig. 2).

\section{Age group III}

Dwell time was longer at $0-25 \mathrm{~m}$, corresponding to 21-54 min (average of $38 \mathrm{~min}$ ) per hour. The longest dwell times were recorded from 01:00 to 12:00 and varied from 39 to $54 \mathrm{~min}$. After 12:00, and until 21:00, dwell time decreased to 21-33 min. The other stratum where age group III remained a considerable time was $26-50 \mathrm{~m}$, corresponding to $5-14 \mathrm{~min} \cdot \mathrm{h}^{-1}$ (average of $10 \mathrm{~min}$ ). The longest dwell times in this stratum were recorded from 13:00 to 23:00 and varied from 12 to $14 \mathrm{~min} \cdot \mathrm{h}^{-1}$. In these 2 strata $(0-25$ and 26-50 m), the average dwell time was $48 \mathrm{~min} \cdot \mathrm{h}^{-1}$. In the remaining strata, dwell time decreased with depth, with longer times spent from 12:00 to 02:00. For depths $>500 \mathrm{~m}$, age group III made 7 visits, 6 during the day (06:00 to 18:00) and only 1 at night (05:00). The time spent at these depths was 20 to $70 \mathrm{~min}$, with an average of $47 \mathrm{~min}$. The deepest swim $(1,432 \mathrm{~m})$ was made during the day $(17: 36)$ and lasted 25 min (Fig. 2).

\section{Internal and ambient temperatures}

The internal and ambient temperatures that were individually recorded in the tags at the maximum depth reached by YFT were, respectively, 24.3 and $6.25^{\circ} \mathrm{C}$ at $746 \mathrm{~m}$ for group I, 23.3 and $2.0^{\circ} \mathrm{C}$ at $1,240 \mathrm{~m}$ for group II, and 24.7 and $3.7^{\circ} \mathrm{C}$ at $1,432 \mathrm{~m}$ for group III. The highest average internal temperature was $24.0,25.0$, and $25.0^{\circ} \mathrm{C}$ for age groups I, II, and III, respectively, and was recorded in the surface stratum. Starting at $50 \mathrm{~m}$ depth, the average internal temperature in the 3 age groups decreased by no more than 3 degrees. By contrast, the ambient temperature decreased with depth, with the highest average ambient temperatures $\left(23.6\right.$ to $25.0{ }^{\circ} \mathrm{C}$ )
1 en el día (09:00). El tiempo que permaneció a estas profundidades fue de 7-12 min, con un promedio de $10 \mathrm{~min}$. El nado más profundo $(746 \mathrm{~m})$ fue realizado a las 09:00 en un tiempo de 12 min (Fig. 2).

\section{Grupo de edad II}

El tiempo de permanencia fue mayor en el estrato de profundidad de $0-25 \mathrm{~m}$, con rangos de permanencia por hora de 35 a 53 min (promedio de $38 \mathrm{~min}$ ). Los mayores tiempos de permanencia en ese estrato fueron registrados de la 01:00 a las 11:00, con rangos de 40 a $53 \mathrm{~min}$, pero la permanencia posteriormente disminuyó de las $12: 00$ a las 24:00, con rangos de 23 a 34 min. El segundo estrato de profundidad

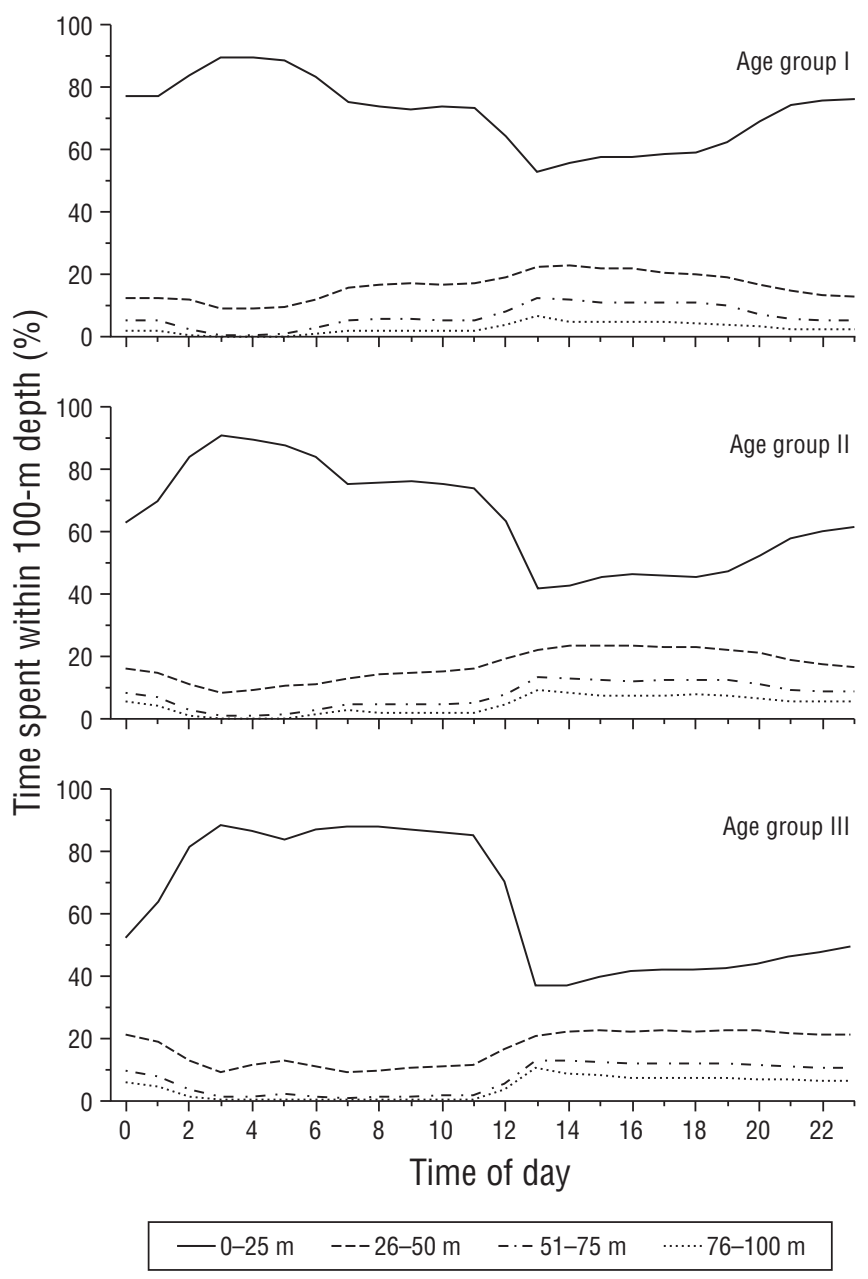

Figure 2. Graphical representation of percent time spent by the different yellowfin tuna, Thunnus albacares, age groups in the upper depth strata (0-25 m, 26-50 m, 51-75 m, y 76-100 m).

Figura 2. Representación gráfica del porcentaje de permanencia de los grupos de edad I, II y III del atún aleta amarilla, Thunnus albacares, en los primeros estratos de profundidad (0-25 m, 26-50 m, 51-75 m y 76-100 m). 
recorded at $0-25 \mathrm{~m}$ and the lowest $\left(5.0\right.$ to $\left.7.2{ }^{\circ} \mathrm{C}\right)$ recorded at $>500 \mathrm{~m}$ (Fig. 3).

The 3 age groups spent more than $80 \%$ of the time in the mixed layer, with age group I being the one that spent the most time (88\%) in that stratum. Fish from age group III showed the highest number of visits to the mixed layer, with a dwell time of $20 \%$. The 3 age groups preferred making visits below the mixed layer during the day rather than during the night. However, this preference was more pronounced in age groups I and II, with daytime dwell times higher than $60 \%$, than in age group III, whose daytime dwell time was comparatively lower (54\%), but higher during the night (Table 3).

\section{Discussion}

The use of archival tags to generate information on YFT movements in the water column proved to be an efficient support tool for understanding vertical swimming behavior during day and night hours. The recapture of YFT of different sizes and with records of more than one year in freedom evidenced that the type of archival tag did not affect fish health. In addition, following the capture, tagging, and release procedures for YFT described by Schaefer et al. (2007) and Schaefer and Fuller (2016) was critical to keep the handling time of the tuna aboard the vessel to a minimum and reduce stress; this was indicated by the signs of strength and vitality of the fish during their release.

Tagged YFT scattered to areas outside the Revillagigedo Archipelago Biosphere Reserve, where they were vulnerable to commercial fishing by Mexican tuna vessels, mainly fishing on dolphin sets or school sets (Aldana 2000, Dreyfus 2008, IATTC 2016). The recapture rate by age group was variable, with medium and large YFT being predominantly caught, thus corroborating the results of Schaefer et al. (1963). This pattern could be explained by little or no presence of floating objects in the area. The vertical movements and the preference of YFT for shallow strata confirmed its classification as an epipelagic species, which spends most of the day in the $0-50 \mathrm{~m}$ water column and is more abundant at depths of up to $100 \mathrm{~m}$ (Collette and Nauen 1983). The 3 age groups complemented the rest of their swimming time with visits to depths of 100 to $500 \mathrm{~m}$ and devoted only a few minutes to occasional dives to depths beyond $500 \mathrm{~m}$ (Schaefer et al. 2007, Schaefer et al. 2011, Schaefer et al. 2014). Although the statistical analysis revealed significant differences between age groups I, II, and III by depth stratum during the day and night, the 3 age groups exhibited a very similar behavior pattern in the water column, spending more time at depths of $0-100 \mathrm{~m}$. This observed pattern contrasts with the one exhibited by bigeye tuna (Schaefer and Fuller 2010). Regarding the depth preferences by age group, small fish (age group I) spent most of the time at $0-25 \mathrm{~m}$ and $26-50 \mathrm{~m}$ and were significantly less abundant in depth strata $>100 \mathrm{~m}$, whereas age groups II and III donde el grupo de edad II permaneció un tiempo considerable fue el de 26-50 m, con un rango de tiempo de permanencia de 6 a $15 \mathrm{~min} \cdot \mathrm{h}^{-1}$ (promedio de $10 \mathrm{~min}$ ). Los mayores tiempos de permanencia en este estrato fueron registrados desde las 12:00 hasta las 24:00, con rango de 12 a $15 \mathrm{~min} \cdot \mathrm{h}^{-1}$. Considerando los 2 estratos de profundidad (0-25 $\mathrm{m}$ y $26-50 \mathrm{~m})$, el tiempo promedio de permanencia fue de $48 \mathrm{~min} \cdot \mathrm{h}^{-1}$. Para el resto de los estratos (de 51 a $500 \mathrm{~m}$ ), la permanencia fue disminuyendo a mayor profundidad, y fueron más consistentes las inmersiones en un horario de 13:00 a 24:00. Con respecto al estrato de profundidad de $>500 \mathrm{~m}$, el grupo de edad II realizó 10 visitas, 6 durante las horas del día (08:00 a 16:00) y 4 durante las horas de la noche (20:00 a 04:00). El tiempo que permaneció a estas profundidades fue de 8 a $65 \mathrm{~min}$, con un promedio de $24 \mathrm{~min}$. El nado más profundo $(1,240 \mathrm{~m})$ fue realizado durante la noche (02:00) en un tiempo de 32 min (Fig. 2).

\section{Grupo de edad III}

El tiempo de permanencia fue mayor en el estrato superficial de $0-25 \mathrm{~m}$, con rangos de permanencia por hora de 21 a $54 \mathrm{~min}$ (promedio de $38 \mathrm{~min}$ ). Los mayores tiempos de permanencia fueron registrados desde la 01:00 hasta las 12:00, con rangos de 39 a 54 min; posteriormente, y hasta las 21:00, la permanencia disminuyó con rangos de 21 a $33 \mathrm{~min}$. El segundo estrato de profundidad donde el grupo de edad III permaneció un tiempo considerable fue el de $26-50 \mathrm{~m}$, con un rango de tiempo de 5 a $14 \mathrm{~min} \cdot \mathrm{h}^{-1}$ (promedio de $10 \mathrm{~min}$ ). Los mayores tiempos de permanencia en este estrato fueron registrados desde las 13:00 hasta las 23:00, con rango de 12 a $14 \mathrm{~min} \cdot \mathrm{h}^{-1}$. Considerando los 2 estratos de profundidad (0-25 m y 26-50 m), el tiempo promedio de permanencia fue de $48 \mathrm{~min} \cdot \mathrm{h}^{-1}$. Para el resto de los estratos, la permanencia fue disminuyendo a mayor profundidad, y fue mayor desde las 12:00 hasta las 02:00. Con respecto a las profundidades $>500 \mathrm{~m}$, el grupo de edad III realizó 7 visitas, 6 durante las horas del día (06:00 a 18:00) y solo 1 durante las horas de la noche (05:00). El tiempo que permaneció a estas profundidades fue de 20 a $70 \mathrm{~min}$, con un promedio de $47 \mathrm{~min}$. El nado más profundo $(1,432 \mathrm{~m})$ fue realizado durante el día (17:36) en un tiempo de 25 min (Fig. 2).

\section{Temperatura interna y del ambiente}

La temperatura interna y la del ambiente, registradas individualmente por las marcas en los AAA a la máxima profundidad alcanzada, fueron, respectivamente, $24.3 \mathrm{y}$ $6.25^{\circ} \mathrm{C}$ a $746 \mathrm{~m}$ para el grupo I, 23.3 y $2.0^{\circ} \mathrm{C}$ a $1,240 \mathrm{~m}$ para el grupo II, y 24.7 y $3.7^{\circ} \mathrm{C}$ a $1,432 \mathrm{~m}$ para el grupo III. El promedio de temperatura interna más alto fue de 24.0, 25.0 y $25.0{ }^{\circ} \mathrm{C}$ para los grupos de edad I, II y III, respectivamente, todos registrados en el estrato superficial. A partir de los $50 \mathrm{~m}$ de profundidad, la temperatura interna promedio para los 3 grupos de edad presentó 
were more abundant in these deeper strata, agreeing with the results of Schaefer et al. $(2011,2014)$.

\section{Deep zone (>500 m)}

The deep-sea swimming activity proved the physiological ability of YFT to dive beyond $500 \mathrm{~m}$ and compensate for low temperatures and minimum oxygen concentrations in this zone. The deep zone is not exclusive to large-sized YFT (age groups II and III) as it was also visited by a small individual from age group I. The deep swimming activity, defined by the number of dives, depth, and dwell time, was
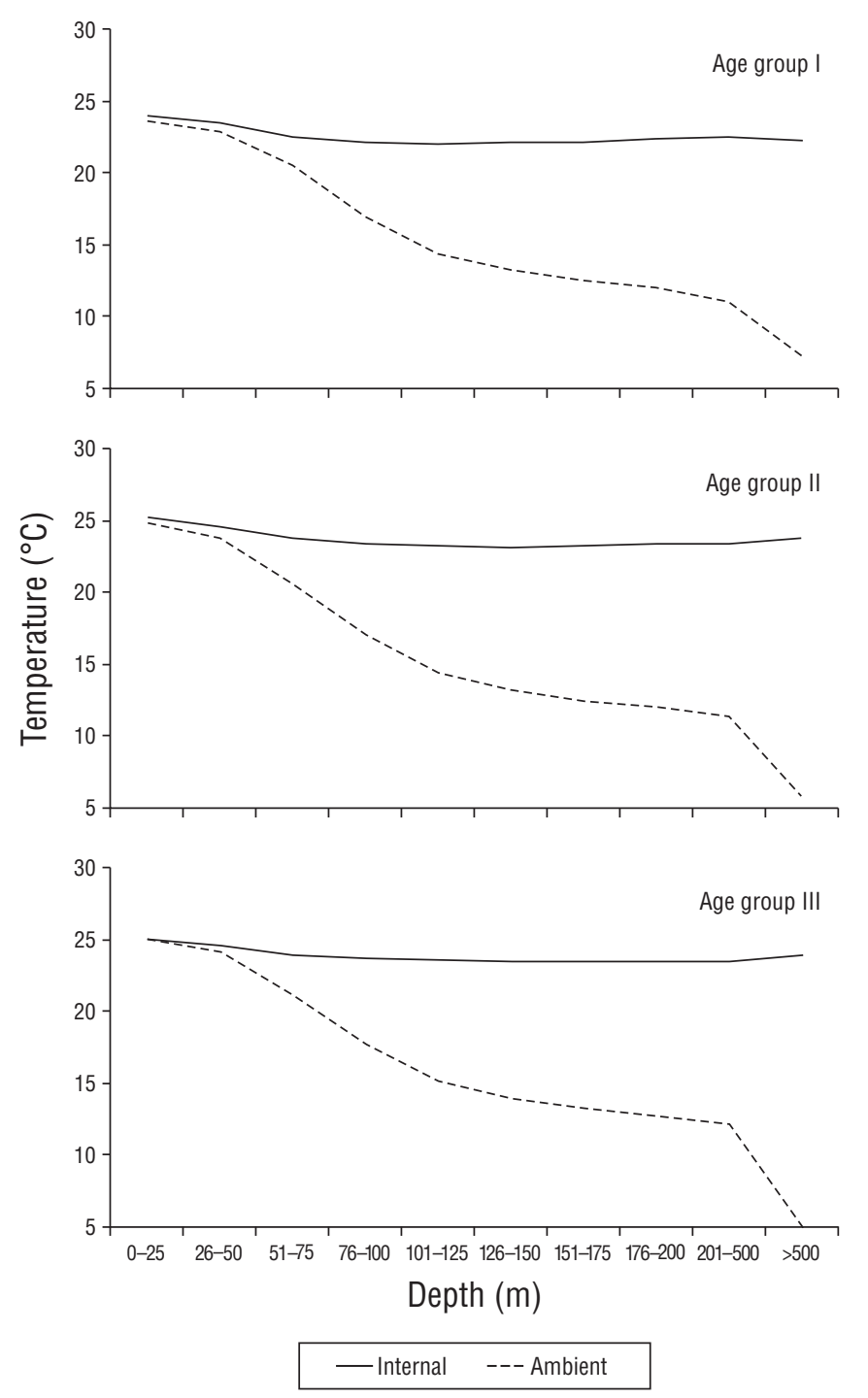

Figure 3. Average ambient and internal temperatures for yellowfin tuna, Thunnus albacares, age groups I, II, and III in different depth strata.

Figura 3. Temperatura promedio interna y del ambiente para los grupos de edad I, II y III del atún aleta amarilla, Thunnus albacares, en diferentes estratos de profundidad. una disminución de no más de 3 grados. Por otra parte, la temperatura del ambiente fue disminuyendo con la profundidad, de tal manera que los promedios de temperatura del ambiente más altos $\left(23.6\right.$ a $\left.25.0{ }^{\circ} \mathrm{C}\right)$ fueron registrados en el estrato de profundidad de $0-25 \mathrm{~m}$ y las temperaturas más bajas $\left(5.0\right.$ a $\left.7.2^{\circ} \mathrm{C}\right)$ fueron registradas en el estrato de profundidad de $>500 \mathrm{~m}$ (Fig. 3).

Los 3 grupos de edad emplearon más del $80 \%$ de su tiempo en la capa de mezcla, y el grupo de edad I fue el que más tiempo invirtió ( $88 \%$ ) en esa zona. Las visitas realizadas por debajo de la capa de mezcla fueron dominadas por el grupo de edad III, con un $20 \%$ de permanencia. Los 3 grupos de edad mostraron preferencia por realizar visitas por debajo de la capa de mezcla durante el día que durante la noche; sin embargo, esta preferencia fue más marcada para los grupos de edad I y II, cuya permanencia durante el día fue por arriba del $60 \%$, que para el grupo de edad III, cuya permanencia fue más baja durante el día (54\%) pero más alta durante la noche (Tabla 3).

\section{DiscuSIÓN}

El uso de marcas archivadoras para generar información sobre el desplazamiento del AAA en la columna de agua resultó ser una herramienta de apoyo para entender el comportamiento de nado vertical durante las horas del día y de la noche. La recaptura de AAA de diferentes tallas y con registros de más de un año en libertad fue evidencia de que el tipo de marca archivadora no afectó la salud del pez. Adicional a esto, el aplicar el procedimiento de captura, marcado y liberación del AAA establecido por Schaefer et al. (2007) y Schaefer y Fuller (2016) fue importante para controlar el tiempo de manejo de los atunes a bordo de la embarcación al mínimo necesario y disminuir el estrés, condición que se cumplió al observar cada atún alejarse de la embarcación con signos de fuerza y vitalidad durante su liberación.

Los AAA marcados se dispersaron hacia zonas fuera de la Reserva de la Biosfera Archipiélago de Revillagigedo, donde fueron vulnerables a la pesca comercial por barcos atuneros mexicanos, principalmente a lances pesqueros sobre cardúmenes asociados a delfines o sobre cardumen libre (Aldana 2000, Dreyfus 2008, IATTC 2016). La tasa de recaptura por grupo de edad fue variable, y predominaron los AAA de talla mediana y grande, lo que coincide con lo reportado por Schaefer et al. (1963). Este patrón puede ser explicado por la poca o nula presencia de objetos flotantes en la zona. Los movimientos verticales y la preferencia del atún por los estratos someros confirmaron su clasificación como especie epipelágica, aquella que invierte la mayoría de las horas del día en la columna de los 0 a $50 \mathrm{~m}$ y tiene presencia importante hasta los $100 \mathrm{~m}$ de profundidad (Collette y Nauen 1983). Los 3 grupos de edad complementaron el resto de su tiempo de nado con visitas a las profundidades de 100 a $500 \mathrm{~m}$ y dedicaron solo unos minutos a realizar inmersiones ocasionales a zonas profundas más allá de los $500 \mathrm{~m}$ 
Table 3. Yellowfin tuna, Thunnus albacares, depth preferences, by age group, taking the depth of the thermocline as the limit.

Tabla 3. Preferencia del atún aleta amarilla, Thunnus albacares, sobre las profundidades, por grupo de edad, considerando como límite la profundidad de la termoclina.

\begin{tabular}{cccccc}
\hline & \multicolumn{2}{c}{ Thermocline } & & \multicolumn{2}{c}{$\%$ time below thermocline } \\
\cline { 2 - 3 } \cline { 5 - 6 } $\begin{array}{c}\text { Age } \\
\text { group }\end{array}$ & $\begin{array}{c}\text { \% time } \\
\text { above }\end{array}$ & $\begin{array}{c}\text { \% time } \\
\text { below }\end{array}$ & & Day & Night \\
\hline I & 88.4 & 11.6 & & 66.4 & 33.6 \\
II & 81.8 & 18.2 & & 61.4 & 38.6 \\
III & 80.3 & 19.7 & & 53.7 & 46.3 \\
\hline
\end{tabular}

associated with the size of YFT, i.e., the smaller the YFT, the shorter the dwell time in the deep zone. On the other hand, age groups II and III showed more visits to depths $>1,000 \mathrm{~m}$ and longer dwell times, which coincides with the deep swimming behavior of YFT reported by Schaefer et al. (2011, 2014). By contrast, as reported for bigeye tuna (Schaefer and Fuller 2010), there was no time pattern or preference for day or night time for deep-sea exploration in any age group. The deep-sea swimming strategy is occasionally used to forage for food, including mesopelagic fish and squid (Graham 1975, Schaefer et al. 2011). A "rebound" swim strategy (from the shallow to the deep zone) was employed by the 3 age groups to compensate for the loss of body heat and oxygen requirements during deep dives (Schaefer et al. 2014).

\section{Internal and ambient temperatures}

The ability of YFT to regulate and maintain their internal temperature above ambient temperature and to explore deep zones is strongly associated with fish size. In deep zones, where there is a sharp difference between fish internal temperature and ambient temperature, small-sized YFT (group I) can lose body heat at a faster rate, explaining the low number of visits to these zones and the minimal dwell times. By contrast, large-sized tuna (older groups) can dive more frequently to deep zones and dwell there for longer periods. According to Brill et al. (1998), after a deep dive, YFT return to the shallow stratum and stay there as long as needed to raise their internal temperature to that of water.

Overall, the 3 age groups preferred spending more time, both during the daytime and nighttime, in the mixed layer, which is considered a comfort zone with appropriate temperature and dissolved oxygen conditions for YFT to satisfy their physiological needs (Schaefer et al. 2014, Hinton 2015). Solar intensity could play a role on these depth preferences. All age groups were noticeably present in the first 2 strata from 06:00 to 12:00. After 12:00 and until sunset, there was an increase in the number of visits to depths beyond the mixed layer, where internal temperature and ambient temperature were markedly different, explaining the minimal dwell time at these depths.
(Schaefer et al. 2007, Schaefer et al. 2011, Schaefer et al. 2014). Si bien el análisis estadístico reveló diferencia significativa entre los grupos de edad I, II y III por estrato de profundidad durante las horas del día y las de la noche, los 3 grupos de edad exhibieron un patrón de comportamiento muy similar en la columna de agua, ya que invirtieron más tiempo a profundidades de $0-100 \mathrm{~m}$, contrario al patrón de comportamiento exhibido por el atún patudo (Schaefer y Fuller 2010). Con respecto a las preferencias de profundidades por grupo de edad, el grupo de peces pequeños (grupo de edad I) fue el que más tiempo exhibió en los estratos de profundidad de $0-25 \mathrm{~m}$ y $26-50 \mathrm{~m}$. En los estratos de profundidad a partir de los $100 \mathrm{~m}$, el grupo de edad I disminuyó significativamente su presencia, mientras que los grupos de edad II y III la incrementaron, lo cual coincide con lo reportado por Schaefer et al. $(2011,2014)$.

\section{Zona profunda $(>500 \mathrm{~m})$}

La actividad de nado a zonas profundas comprobó la capacidad fisiológica del AAA para realizar inmersiones más allá de los $500 \mathrm{~m}$ y compensar las bajas temperaturas y las concentraciones mínimas de oxígeno en la zona. Se pudo comprobar que la zona profunda no es exclusiva para los AAA de talla grande (grupos de edad II y III), ya que fue visitada por un ejemplar pequeño del grupo de edad I. La actividad de nado profundo, definida mediante el número de inmersiones, la profundidad y el tiempo de permanencia, estuvo relacionada con el tamaño del AAA; es decir, entre más pequeño el AAA, menor fue su presencia en la zona profunda en comparación con los ejemplares de mayor tamaño (grupos de edad II y III), para los cuales se registraron un mayor número de visitas, exploraciones más allá de los $1,000 \mathrm{~m}$ de profundidad y tiempos de permanencia más prolongados, lo cual coincide con el comportamiento de nado profundo del AAA reportado por Schaefer et al. $(2011,2014)$. Por otra parte, no se observó para los grupos de edad I, II y III un patrón de tiempo o preferencia por las horas del día o de la noche para realizar exploraciones a zonas profundas, como fue reportado para el atún patudo (Schaefer y Fuller 2010). La estrategia de nado profundo es realizada ocasionalmente para explorar áreas en búsqueda de alimento, como peces y calamares mesopelágicos (Graham 1975, Schaefer et al. 2011). Un comportamiento observado en los 3 grupos de edad es el nado de "rebote" (de zona somera a zona profunda) realizado para compensar la pérdida de calor corporal y los requerimientos de oxígeno al realizar inmersiones profundas (Schaefer et al. 2014).

\section{Temperatura interna y del ambiente}

La capacidad de los AAA para regular y mantener la temperatura interna por arriba de la temperatura del ambiente y para realizar exploraciones a zonas profundas está fuertemente relacionada con el tamaño del atún. En zonas profundas, donde existe una diferencia muy marcada entre la temperatura 
As the day progressed and until the night hours, there was an increase in the number of visits to depths beyond $200 \mathrm{~m}$ in all age groups.

Given the importance of the YFT fishery (IATTC 2018), continued tagging studies in other Pacific regions off the Mexican coasts are recommended. Moreover, supplementary information should continue to be provided for use with data on YFT horizontal movements and vertical habitat use so the information can altogether be included in stock assessment models that enable managers to make recommendations for the sustainability of the resource.

\section{ACKNOWLedgments}

The Mexican National Fisheries and Aquaculture Institute provided support for field research and designated the second author as partaker in the IATTC tagging project in the Revillagigedo Archipelago. We thank IATTC for facilitating data and assigning research staff for the field work and data analyses. We also thank the Universidad Autónoma de Nayarit graduate program for providing us with academic support for the conclusion of this research. Fideicomiso de Investigación para el Desarrollo del Programa Nacional de Aprovechamiento del Atún y de Protección de Delfines y Otros en Torno a Especies Acuáticas Protegidas (The Research Trust for the Development of the National Program for Exploitation of Tuna and Protection of Dolphins and Other Protected Aquatic Species) appointed observers for tagging trips to the Revillagigedo Archipelago and provided the resources needed for the publication of this manuscript.

\section{English translation by EDITAGE.}

\section{REFERENCES}

Aldana FG. 2000. Análisis por tipo de lance de las frecuencias de longitudes del atún aleta amarilla (Thunnus albacares, Bonatere, 1865), obtenidas mediante un diseño de muestreo probabilístico a bordo de barcos cerqueros mexicanos. MSc thesis, Universidad Autónoma de Nuevo León, Nuevo Leon, Mexico, $84 \mathrm{pp}$.

Brill RW, Lowe TE, Cousins KL. 1998. How water temperature really limits the vertical movements of tuna and billfishes-it's the heart stupid. In: Gamperl K, Farrell A, MacKinlay D (eds.), Fish Cardiovascular Function: Control Mechanisms and Environmental Influences. International Congress on the Biology of Fish; 26-30 Jul 1998. American Fisheries Society, Baltimore (MD), pp. 57-62.

Collete BB, Nauen CE.1983. FAO species catalogue, vol. 2. Scombrids of the world: An annotated and illustrated catalogue of tunas, mackerels, bonitos and related species known to date. FAO Fish. Synop. 125 (2): 137pp.

[DOF] Diario Oficial de la Federación. 1994 Jun 6. Decreto por el que se declara como área natural protegida con el carácter de reserva de la biosfera, la región conocida como Archipiélago de Revillagigedo, integrada por cuatro áreas: Isla San Benedicto, Isla Clarión o Santa Rosa, Isla Socorro o Santo Tomás e Isla Roca Partida. Secretaría de Gobernación, Mexico City. interna y la del ambiente, los AAA pequeños (grupo de edad I) pueden perder calor más rápido, lo que explica el bajo número de inmersiones y el tiempo mínimo de permanencia, a diferencia de los atunes grandes (mayor edad), que por su tamaño pueden exhibir un número mayor de inmersiones y un tiempo de permanencia más prolongado. De acuerdo con Brill et al. (1998), después de un nado profundo, el AAA regresa al estrato somero y se mantiene ahí el tiempo necesario para elevar la temperatura interna a la del ambiente.

En general, los 3 grupos de edad manifestaron preferencia por invertir más tiempo del día y de la noche en la capa de mezcla, que es considerada como una zona de confort donde el AAA encuentra las condiciones adecuadas de temperaturas y oxígeno disuelto para satisfacer sus necesidades fisiológicas (Schaefer et al. 2014, Hinton 2015). Es posible que la intensidad de luz solar tenga un efecto en esas preferencias de profundidad, ya que desde las 06:00 hasta las 12:00 fue marcada la presencia de los grupos de atunes en los 2 primeros estratos de profundidad $\mathrm{y}$, posterior a esta hora $\mathrm{y}$ hasta el atardecer, incrementaron las inmersiones más allá de la capa de mezcla, donde la diferencia de temperatura interna y del ambiente fue más marcada, lo que explica el tiempo mínimo de permanencia en estas profundidades. A medida que fue avanzando el día y hasta las horas de la noche, incrementaron las inmersiones a profundidades superiores a los $200 \mathrm{~m}$ para los 3 grupos de edad.

Debido a la importancia de la pesquería de AAA (IATTC 2018), se recomienda continuar con los estudios de marcado en otras regiones del océano Pacifico frente a las costas mexicanas. Además, se recomienda seguir complementando la información de desplazamiento horizontal y utilización del hábitat vertical del AAA e incorporar esta información a modelos de evaluación de la población pesquera que permiten proponer recomendaciones de manejo para la sustentabilidad del recurso.

\section{Agradecimientos}

El Instituto Nacional de Pesca y Acuacultura (México) brindó apoyo para realizar cada uno de los viajes de investigación y designó al segundo autor a formar parte del proyecto de marcado de la CIAT en el archipiélago de Revillagigedo. Agradecemos a la CIAT la información y el apoyo brindado mediante su staff de investigadores para el trabajo de campo y el análisis de la información. Agradecemos también al posgrado de la Universidad Autónoma de Nayarit la orientación y el apoyo académico brindados para la culminación del trabajo de investigación. Así mismo, agradecemos al Fideicomiso de Investigación para el Desarrollo del Programa Nacional de Aprovechamiento del Atún y de Protección de Delfines y Otros en Torno a Especies Acuáticas Protegidas la designación de observadores a bordo para cubrir algunos viajes de marcado en el archipiélago de Revillagigedo y el apoyo para la publicación del presente artículo. 
[DOF] Diario Oficial de la Federación. 1999 May 17. Promulgación del Acuerdo sobre el Programa Internacional para la Conservación de los Delfines, adoptado en la ciudad de Washington, D.C., Estados Unidos de América, el veintiuno de mayo de mil novecientos noventa y ocho. Diario Oficial de la Federación. Secretaría de Relaciones Exteriores, Mexico City.

[DOF] Diario Oficial de la Federación. 2014 Jan 16. Norma Oficial Mexicana NOM-001-SAG/PESC-2013, Pesca responsable de túnidos. Especificaciones para las operaciones de pesca con red de cerco. Secretaría de Gobernación, Mexico City.

Dreyfus LM. 2008. Impacto de los diferentes tipos de lances con red de cerco en la pesca del atún aleta amarilla en el Pacifico Oriental. El Vigía, Ensenada (Baja California, Mexico), 13(34):7.

Fiedler PC, Lynne DT. 2006. Hydrography of the eastern tropical Pacific: A review. Prog. Oceanogr. 69 (2006) 143-180. https://doi.org/10.1016/j.pocean.2006.03.008

Hinton MG. 2015. Las condiciones oceanográficas en el OPO y sus efectos sobre las pesquerías atuneras = Oceanographic conditions in the EPO and their effects on tuna fisheries. InterAmerican Tropical Tuna Commission, Scientific Advisory Committee, sixth meeting 11-14 May 2015, La Jolla (CA). Document SAC-06 INF-C.

[IATTC] Inter-American Tropical Tuna Commission. 2016. Tunas, billfishes and other pelagic species in the Eastern Pacific Ocean in $2015=$ Los atunes, peces picudos y otros peces pelágicos en el océano Pacifico Oriental en 2015. IATTC, La Jolla (CA). [Accessed FECHA DE ACCESO] Fishery Satus Report, No. 14. http://www.iattc.org/PDFFiles/FisheryStatusReports/ Spanish/No-14-2016_Atunes, $\% 20$ peces $\% 20$ picudos $\% 20 y \% 20$ otros $\% 20$ peces $\% 20$ pelagicos $\% 20$ en $\% 20$ el $\% 20$ Oceano $\% 20$ Pacifico\%20oriental\%20en\%202015.pdf.

[IATTC] Inter-American Tropical Tuna Commission. 2018. Informes mensuales de capturas y datos 2007-2017. [Accessed FECHA DE ACCESO] Comisión Interamericana del Atún Tropical. http://www.iattc.org/MonthlyReports.htm.

Graham JG.1975. Heat exchange in the yellowfin tuna, Thunnus albacares, and skipjack tuna, Katsuwonus pelamis, and the adaptive significance of elevated body temperatures in scombrid fishes. Fish. Bull. 72: 219-229.

Lyman MO.1993. An Introduction to Statistical Methods and Data Analysis. 4th ed. Duxbury Press, Belmont (CA).
Montgomery DC.1991. Design and Analysis of Experiments. 3rd ed. John Wiley and Sons, Hoboken (NJ).

Portela E, Beier E, Barton ED, Castro R, Godínez V, PalaciosHernández E, Fiedler PC, Sánchez-Velasco L, Trasviña A. 2016. Water masses and circulation in the tropical Pacific off central Mexico and surrounding areas. American Meteorological Society. https://doi.org/10.1175/JPO-D-16-0068.1

Quinn GP, Keough MJ. 2002. Experimental Design and Data Analysis for Biologist. Cambridge University Press, New York, $537 \mathrm{pp}$.

Schaefer MB, Chatwin BM, Broadhead GC. 1963. Some results of tagging and recovery of tropical tunas 1955-1959. Int. Comm. Northwest Atl. Fish., Spec. Publ. 4: 306-307.

Schaefer KM, Fuller DW. 2010. Vertical movements, behavior, and habitat of bigeye tuna (Thunnus obesus) in the equatorial eastern Pacific Ocean, ascertained from archival tag data. Mar. Biol. 157: 2625-2642. https://doi.org/10.1007/s00227-010-1524-3

Schaefer KM, Fuller DW. 2016. Methodologies for investigating oceanodromous fish movements: archival and pop-up satellite archival tags. pp. 251-289. In: Morais P, Daverat F (eds.), An Introduction to Fish Migration. CRC Press, Boca Raton (FL).

Schaefer KM, Fuller DW, Block BA. 2007. Movements, behavior, and habitat utilization of yellowfin tuna (Thunnus albacares) in the northeastern Pacific Ocean, ascertained through archival tag data. Mar. Biol.152(3): 503-525. https://doi.org/10.1007/s00227-007-0689-x

Schaefer KM, Fuller DW, Block BA. 2011. Movements, behavior, and habitat utilization of yellowfin tuna (Thunnus albacares) in the Pacific Ocean off Baja California, Mexico, determined from archival tag data analyses, including unscented Kalman filtering. Fish. Res. 112: 22-37.

Schaefer KM, Fuller DW, Aldana G. 2014. Movements, behavior, and habitat utilization of yellowfin tuna (Thunnus albacares) in waters surrounding the Revillagigedo Islands Archipelago Biosphere Reserve, Mexico. Fish. Oceanogr. 23(1): 65-82. https://doi.org/10.1111/fog.12047

Wild A. 1986. Growth of yellowfin tuna, Thunnus albacares, in the eastern Pacific Ocean based on otolith increments. Inter-Am. Trop. Tuna Comm. Bull. 18: 421-482.

Received August 2018, accepted October 2018. 